\title{
Factors Affecting the Competitive Advantage for the Marketing of Educational Services in Jordanian Universities: Case of Zarqa University
}

\author{
Mustafa S. Al-Shaikh ${ }^{1}$ \\ ${ }^{1}$ Faculty of Economics and Administrative Sciences, Zarqa University, Jordan \\ Correspondence: Mustafa S. Al-Shaikh, Associate Professor, Faculty of Economics and Administrative Sciences, \\ Zarqa University, P. O. Box 132222, Zarqa 13132, Jordan. Tel: 962-79-553-1042. E-mail: \\ dr.mustafa1971@hotmail.com
}

Received: June 23, $2015 \quad$ Accepted: July 10, $2015 \quad$ Online Published: September 29, 2015

doi:10.5539/ijms.v7n5p147 URL: http://dx.doi.org/10.5539/ijms.v7n5p147

\begin{abstract}
The study aims at determining the competitive advantage impact on marketing Jordanian universities based on the different dimensions of the study (Gender, level of the student, specialization, methods of payment of university fees, and nationality). The population of the study on the Zarqa University students is totally 200 . A stratified proportional-random sample is selected in order to answer the questions posed in the questionnaire. Data have been processed and analyzed through the use of "SPSS" program in order to obtain means, standard deviations, and percentages for the demographic characteristics of the sample. Moreover, the questionnaire included two parts (1) demographic variables (22 items) by (Mazzarol \& Soutar, 2012), and (2) competitive advantage (5 items) by (Barney, 1991; Hamel \& Prahalad, 1994). The analysis of variance (ANOVA) is conducted to test if there are any statistical evidences of the existence of the difference between participants to the independent variables. The study revealed that there are strong significant statistical evidences between the impacts of competitive advantage on marketing Jordanian universities. These differences were due to the following factors: gender of the student, level of the student, specialty of the student, nationality of the student and methods of payment.
\end{abstract}

Keywords: competitive advantage, services marketing, Jordan, Zarqa University

\section{Introduction}

Marketing is increasingly becoming extremely competitive worldwide in general and in the field of education particularly. That is why the competition in this field is increasing day by day, and describes situations or activities in which firms compete with each other. Competitive advantage strategy is the search for a favorable competitive position in an industry. This is the function of both the attractiveness of the industry and the relative competitive position within that particular industry, as well as alternative activities that an organization can undertake. Competitive strategy aims to establish a profitable and sustainable position against the forces that determine industry competition (Porter, 1991).

Understanding competitive advantage is an ongoing challenge for decision makers. Historically, competitive advantage was thought of as a matter of position, where firms occupied a competitive space and built and defended market share. Competitive advantage depended on where the business was located and where it chose to provide services. Stable environments allowed this strategy to be successful, particularly for large and dominant organizations in mature industries (Duncan et al., 1998).

Competitiveness is, therefore, defined as the effort and achievement of long term profitability, above the average of the particular industry within which they operate as well as above alternative investment opportunities in other industries. This definition includes, therefore, the concept of opportunity cost and illustrates that successful organizations should not only compete within their particular industry but also against other investment opportunities.

Sustained competitive advantage has become more of a matter of movement and ability to change than of location or position (Stalk et al., 1992). When referring to educational services, competitiveness should also include the sustainability of local resources for ensuring the maintenance of long term success as well as the 
achievement of equitable returns-on-resources utilized to satisfy all stakeholders (Buhalis, 2008).

Business education is often viewed as fundamentally about rational and analytical thinking, but creativity and innovation are also central. Information technology and globalization, they may be even more fundamental to business success than ever before. Both educators and managers can benefit from thinking about creativity and innovation in this context, since both are responding to the same business trends, and developing the same people.

Since business fundamentals should reflect business realities in education, global trends in information and communications technology and mass migration brought on by information and communications technology are explored, and their relevance to the imagination and creativity is developed. Educational innovations in motivation and aspiration capacity should be relevance to fundamental business education (McManus, 2014). The importance of service quality means of achieving long-term competitive advantage in higher education .It further seeks to explore the influences of customer expectation, course design and delivery as well as learning support on service quality (Yeo, 2008). This research is justified by the existence of few and fragmented researches regarding the theme. In this way, the contribution of this work is to join the factors affecting the competitive advantage for the marketing of educational services in Jordanian universities. Due to the competitive environment in universities, which is very tough and critical, it is very important for universities to investigate all factors that can be effective in competitive advantage. This fact forced universities to investigate more and more in details regarding the variables that are responsible for changing customer point view regarding their competitive advantage such as their gender, level of student, specialization, methods of payment, and nationality.

\section{Literature Review}

Competitive advantage mean in the context of public higher education institutions is to critically investigate the discourse of competitive advantage in the life and activities of public higher education institutions (PHEIs). 73 interviews at 16 Dutch PHEIs were conducted, the conclusion showed that the business way of defining competitive advantage should be critically reviewed and verified in the context of the public higher education sector Haan (1987). Furthermore, Yeo \& Li (2014) in their paper explored the influences of service quality in higher education and how they contribute to the overall performance of a higher learning institution in Singapore. It draws on the underpinnings of SERVQUAL, and discusses the dichotomy and interrelation between customer perception and expectation in response to current tertiary contexts. Based on an actual framework of a Singapore higher learning institution, the paper further examines three key aspects of service standards: customer orientation, course design/delivery, and support services. Qualitative methodology was employed and data were collected by means of structured in-depth interviews with 12 academics of the institution. Our findings reveal that the way students are perceived will have a direct influence on the learning dynamics that occur both inside and outside the classroom. More importantly, service quality needs to be evaluated on the basis of the integrated experience of students supported by a network of learning spaces created to promote dialogue, inquiry, and reflection. At the core is the collective effort of all individuals that function as active carriers of change.

A study by Lim and Svensson (2013) aim to embedding critique in the university, new roles for critical marketing education explain the embedding critique in the university: a new role for critical marketing education. The paper shows how a critical marketing education offers a pragmatic means of preparing university students to become active and critical voices of society. Fernandes et al. (2013) in their paper titled understanding student satisfaction and loyalty in the UAE in higher education sector. Verify and estimate the impact of the antecedents of programme satisfaction and to explore its link with student loyalty in the Higher Education (HE) sector in the United Arab Emirates (UAE). A Programme experience questionnaire (PEQ) was developed, based on the national student survey (NSS), which surveyed 187 graduates at a British university based in the UAE. Teaching quality and variables directly associated with the students' programme of study had the most significant impact on student satisfaction emphasizing the need for recruitment and development of high quality academic faculty members. Academic feedback, library and IT resources did not have a significant impact. The link between Programme satisfaction and satisfaction with non-academic services and facilities had a positive impact on student loyalty.

While Zebal and Goodwin (2012) in the paper that they gave the entitled market orientation and performance in private universities. Support the theoretical arguments that the universities can be successful in attaining their business performances by initiating and adopting market oriented activities. The study further argues why it is so critical for a private university to be market oriented and how this market orientation can be attained.

Mazzarol and Soutar (2012) provide a strategic overview of the state of international education and a unique perspective on the trends that have shaped and will continue to shape this industry into the future. The paper is 
an expert opinion that draws on global trends in the international education sector. Since the publication of the authors' book, the global market for higher education has changed significantly. A decade ago competition was between a few mainly English language instruction countries in the developed world.

Gallego-Álvarez et al. (2011) analyze how several variables, such as universities' profitability, growth-reduction of student numbers, age tradition, type of university and internationality, among others, influence the transparency practices of Spanish universities as well as the technology, interactivity, structure and navigability of their web pages. First a content analysis of the Spanish universities' websites is carried out. To do this a disclosure index is created and applied. This index is more complex than those in previous papers, focusing on several issues, such as financial information, corporate governance, social responsibility, research, teaching activities, strategic information, timeliness, contact information, technology, interactivity with users, navigability and web structure.

Takes a critical view of customer metaphor for students and argues that such attempts restrict the rights and privileges that students and the HE sector traditionally enjoyed. Differences between commercial organizations and HE sector in terms of products developed and the underlying process of development are explored. How the uniqueness of the HE sector relies more on a sector-wide agreement than on legal framework is analyzed. The role of marketing units in developing a mature market which is strong enough to demand quality HE products is emphasized. Several aspects that need to be coordinated among quality assurance departments, academic staff, and the marketing departments are discussed Ramachandran (2010).

Mourad (2010) in her paper students' adoption of an open access online education service: an exploratory study in an emerging higher education (HE) market.Seeks to investigate students' adoption of an open access online education service in higher education and their perceptions of its attributes as an innovation in an emerging market. The results indicate that, besides the perceived attributes of the innovation being the main determinant of the students' adoption of it, a number of internal factors within the university and external factors within the educational market in Egypt directly influence the adoption process.

The originality of the paper is in its empirical work as it adapted a well-known theory, the perceived attributes of innovation model, and empirically tested it in a specific context: the higher education market in a developing country (Burdett \& Crossman, 2010).

Petruzzellis and Romanazzi (2010) in the paper presented by them entitled educational value: how students choose university: evidence from an Italian university. Their paper aims to measure students' perceptions of value that are influenced by differences in costs (monetary and non-monetary), students' attitudes and socio-demographic features. It seeks to investigate the components of the university value that affects students' choice. A questionnaire was developed in order to measure students' beliefs and perceptions about the offer and service attributes of the university. All variables, primarily drawn from the literature, were measured using multiple items. ANOVA and a PLS regression was used to investigate the effects of the various value dimensions as perceived by students. The findings suggest that, although universities could improve student retention by attempting to increase their level of satisfaction, their efforts will be more effective if focused on demonstrating the way that the service provided has helped their customers to achieve their objectives, highlighting the strategic importance of the social value.

Encourage the development of a research stream on the market orientation concept in higher education. Specifically, the author explains why this concept has emerged as a potentially relevant strategy to manage higher educational institutions. The paper raises the main problems surrounding the use of market orientation in higher education, and thereby, suggests an extensive research agenda which is expected to improve the importation of marketing concepts in higher education (Akonkwa, 2009) and (Stanton, 2006). Thus, the Competitive advantage have a vital role in the educations in general and especially in privet education, that why this study focus in private universities. Therefore, these universities have high competitive in the local market.

\section{Theoretical Background}

Competitive advantage is a set of unique features of a company and its products that are perceived by the target market as significant and superior to the competition. It is the reason behind brand loyalty and why you prefer one product or service over another. There are different types of competitive advantages that companies can actually use; they are cost competitive advantage and product/service differentiation (Lombardo, 2015). Competitive advantage refers to ultimately built and maintained by adding value to customers (Prahalad \& Hamel, 1990). Value is added by cost leadership, i.e.offering equal quality products or services at a lower cost than competitors, or by differentiation, i.e.offering products or services that are perceived to be unique relative to some important characteristic. Understanding how each competitively relevant resource and capability affects 
costs and uniqueness is an important aspect of understanding how, or if, each adds value to the services provided (Duncan et al., 1998). Researcher suggests a model of study as shown in figure 1.

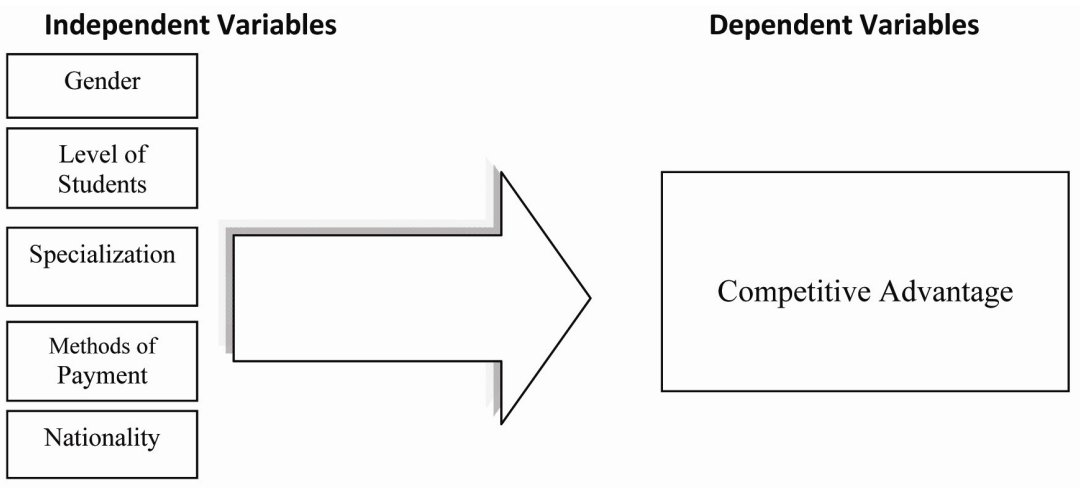

Figure 1. Model of study

According to Porter's five forces theory, firm's profitability is influenced by its relative size compared to its industry rivals, suppliers and customers (Porter, 1985). For a university, customer can be thought as students; suppliers can be thought as staff. In higher education industry, the good transportation infrastructure and wellconnected metropolitan universities have some advantages against the treat of entry, to attract good staff and more students. The place of university can decrease of treatment of rival and a good place has certainly positive effects on staff and students. That is to say, location is an opportunity for universities to attract the students (Aydin, 2013).

Porter's five-force model of competition (1985) has been widely used an analytical tool to analyze the intensity of competition and to identify the level of profitability of an industry. This model also is used to determine to find the ways for defending or to develop some strategies against the competitive forces. The results of five forces assess the level of competition of an industry, and the ability of firms in an industry to make profits. Porter's five-force model of competition has five elements ,threat of substitutes, bargaining power of buyers , threat of entrants, competitive rivalry ,bargaining power of suppliers .The other model is the resource-based view. This view emerged as a complement or dual to Porter's theory of competitive advantage (Barney \& Arikan, 2001). It is an alternative view of the firm for competitive advantage. The subject of firm capabilities is as one source of competitive advantage.

Wernerfelt (1984) developed a theory of competitive advantage which based on the resources for developing a firm. He shows the examples of resources are brand name, in-house knowledge of technology, employment of skilled personnel, trade contact, machinery, efficient procedures and capital. As such, both tangible and intangible assets are considered a firm's resources.

In order for a competence to be a competitive advantage, three criteria have to be met: the competence has to provide access to more than one market, give a significant contribution to the end products, and be difficult for competitors to imitate (Hamel \& Prahalad, 1994).

Accordingly, if a company possesses a core competence and understands how to take advantage of it, it can lead to sustained competitive advantages. In addition, resource-based theory is based on the assumption that firms are fundamentally heterogeneous regarding their resources and internal competencies. It deals with the problem of how firms can exploit their internal resource base and capabilities to obtain sustained competitive advantages (Barney, 1991; Hamel \& Prahalad, 1994).

1) Cost competitive advantage is when a company is able to utilize its skilled workforce, inexpensive raw materials, controlled costs, and efficient operations to create maximum value to consumers. There are a few other important ways that costs can be kept lower in order for a company to use a cost competitive advantage. Reengineering is used by companies that are able to cut costs by redesigning and creating improvements to their products. Finally, some companies create a new delivery method for their product or service, resulting in large cost savings that they can share with their customers.

2) Another way that companies can have a competitive advantage in the marketplace is through product/service differentiation. If a company's product or service has a valuable, unique offering for its consumers, then loyalty and product/service differentiation can occur. Cost competitive advantages can easily disappear with the introduction of a new competitor or new technology. If a company offers a unique product or service, it is harder 
to maintain an edge in the market based on price alone. The company must offer something to the consumer besides just a low price. However, the construct of model bases on past studies such as competitive advantage (Barney, 1991; Hamel \& Prahalad, 1994), and demographic variables (Mazzarol \& Soutar, 2012). Therefore, the present study comes to answer the following questions:

1) Is there any difference toward competitive advantage due to gender of the student?

2) Is there any consistency toward competitive advantage due to level of the student?

3) Is there any consistency toward competitive advantage due to specialization of the student?

4) Is there any consistency toward competitive advantage due to methods of payment?

5) Is there any consistency toward competitive advantage due to nationality of the student?

\section{Hypotheses}

The following hypotheses were examined:

H1: There are no statistical differences $(\alpha \leq 0.05)$ between students due to the gender of the students towards competitive advantage on marketing of Jordanian universities.

H2: There are no statistical differences $(\alpha \leq 0.05)$ between students due to the level of the students towards the impact of competitive advantage on marketing of Jordanian universities.

H3: There are no statistical differences $(\alpha \leq 0.05)$ between students due to the specialization of the students towards the impact of competitive advantage on marketing of Jordanian universities.

H4: There are no statistical differences $(\alpha \leq 0.05)$ between students due to the methods of payment of university fees by the students towards the impact of competitive advantage on marketing of Jordanian universities.

H5: There are no statistical differences $(\alpha \leq 0.05)$ between students due to the nationality of the students towards the impact of competitive advantage on marketing of Jordanian universities.

\section{Methodology}

Participants involved in this study were identified entirely through the registration department at Zarqa University. The population of the study is the Zarqa University students, totally 200. A stratified proportional-random sample is selected in order to answer the questions posed in the questionnaire. The questionnaire included two parts (1) demographic variables (22 items) by (Mazzarol \& Soutar, 2012), and (2) competitive advantage (5 items) by (Barney, 1991; Hamel \& Prahalad, 1994). Table 1 shows the sample distribution according to the demographic variables. Figures show that the majority $(51.0 \%)$ of the sample is males. $29.5 \%$ of the students in the Second year and $44.5 \%$ are in humanities, $69.5 \%$ are Jordanian and $68.0 \%$ have family support fees. The first step in developing this research instrument was an extensive and in-depth literature review. The questionnaire was measured on a 1 to 5 Likert scale. Second, many practitioners critiqued the instrument. After numerous iterations, improvements were incorporated into the survey. The study adopts two sources of data: secondary and primary data. Secondary data are obtained from literature published in this subject including previous studies. The primary data are collected from field study conducted through a questionnaire that was developed for such purpose. The questionnaire consists of two parts: The first part included general data of personal variables: Gender, Study Level of the student, specialization, methods of payment of university fees, and Nationality. The second part included (20) items representing competitive advantage impact on the marketing of Jordanian universities.

\section{Results of the Study}

\subsection{Reliability}

Academic staff from the Jordanian universities as well as specialists in marketing have evaluated the questionnaire. For further validity test, the responses of (21) students of the sample were tested and evaluated. Reliability with composite measures is evaluated for the internal consistency through the "Cronbach's Alpha" measure. The higher the Cronbach's Alpha value, the greater is the internal consistency of the items, making up a composite measure. The Alpha's for the items are not below (0.78) as shown in Appendix A. Therefore, it can be concluded that the reliability of the questionnaire is high. 
Table 1. Sample distribution

\begin{tabular}{lll}
\hline Variable & Frequency & $\%$ \\
\hline Gender & 102 & 51.0 \\
Male & 98 & 49.0 \\
Female & & \\
Level & 49 & 24.5 \\
First years. & 59 & 29.5 \\
Second years. & 40 & 20.0 \\
Third years. & 36 & 18.0 \\
Forth years. & 16 & 8.0 \\
Fifth years. & & \\
Special & 89 & 44.5 \\
Humanities & 83 & 41.5 \\
Sciences & 28 & 14.0 \\
others & & \\
Nationality & 139 & 69.5 \\
Jordanian & 61 & 30.5 \\
Non -Jordanian & & \\
Methods of payment & 136 & 68.0 \\
Family & 33 & 16.5 \\
Scholarship & 23 & 11.5 \\
Relatives & 8 & 4.0 \\
Job & & \\
\hline
\end{tabular}

Table 2. Descriptive statistics

\begin{tabular}{lll}
\hline & Mean & Std. Deviation \\
\hline q1 & 4.0600 & 1.40937 \\
q2 & 4.3400 & 1.24586 \\
q3 & 4.2950 & 1.31017 \\
q4 & 4.3500 & 1.22269 \\
q5 & 4.5400 & .97114 \\
q6 & 4.1800 & 1.40265 \\
q7 & 4.1950 & 1.50943 \\
q8 & 4.3850 & 1.21828 \\
q9 & 4.5250 & .84436 \\
q10 & 4.7700 & 3.68442 \\
q11 & 4.6150 & .70659 \\
q12 & 4.7350 & .57132 \\
q13 & 4.8350 & .44583 \\
q14 & 4.4650 & .87900 \\
q15 & 4.4750 & .97165 \\
q16 & 4.3500 & 1.12866 \\
q17 & 4.4850 & .90769 \\
q18 & 4.5200 & .85042 \\
q19 & 4.4450 & 1.04520 \\
q20 & 4.0450 & 1.40100 \\
Valid N & & \\
(listwise) & & \\
\hline
\end{tabular}

Table 3. T-test for the gender variable

\begin{tabular}{llllllll}
\hline gender & & $\mathrm{q} 1$ & $\mathrm{q} 4$ & $\mathrm{q} 6$ & $\mathrm{q} 8$ & $\mathrm{q} 9$ & $\mathrm{q} 19$ \\
\hline \multirow{1}{1.00}{} & Mean & 3.9706 & 4.2059 & 3.9608 & 4.2647 & 4.3824 & 4.3627 \\
& $\mathrm{~N}$ & 102 & 102 & 102 & 102 & 102 & 102 \\
& Std. Deviation & 1.49888 & 1.35221 & 1.64661 & 1.36379 & .98548 & 1.11506 \\
\hline 2.00 & Mean & 4.1531 & 4.5000 & 4.4082 & 4.5102 & 4.6735 & 4.5306 \\
& $\mathrm{~N}$ & 98 & 98 & 98 & 98 & 98 & 98 \\
& Std. Deviation & 1.31095 & 1.05762 & 1.05358 & 1.03789 & .63855 & .96542 \\
\hline \multirow{2}{*}{ Total } & Mean & 4.0600 & 4.3500 & 4.1800 & 4.3850 & 4.5250 & 4.4450 \\
& $\mathrm{~N}$ & 200 & 200 & 200 & 200 & 200 & 200 \\
& Std. Deviation & 1.40937 & 1.22269 & 1.40265 & 1.21828 & .84436 & 1.04520 \\
\hline
\end{tabular}


Table 4. ANOVA for the level variable

\begin{tabular}{|c|c|c|c|c|c|c|}
\hline & & Sum of Squares & $\mathrm{df}$ & Mean Square & $\mathrm{F}$ & Sig. \\
\hline \multirow[t]{3}{*}{$\mathrm{q} 5$} & Between Groups & 16.144 & 4 & 4.036 & 4.588 & .001 \\
\hline & Within Groups & 171.536 & 195 & .880 & & \\
\hline & Total & 187.680 & 199 & & & \\
\hline \multirow[t]{3}{*}{ q8 } & Between Groups & 20.148 & 4 & 5.037 & 3.569 & .008 \\
\hline & Within Groups & 275.207 & 195 & 1.411 & & \\
\hline & Total & 295.355 & 199 & & & \\
\hline \multirow[t]{3}{*}{ q15 } & Between Groups & 17.711 & 4 & 4.428 & 5.074 & .001 \\
\hline & Within Groups & 170.164 & 195 & .873 & & \\
\hline & Total & 187.875 & 199 & & & \\
\hline \multirow[t]{3}{*}{ q19 } & Between Groups & 15.660 & 4 & 3.915 & 3.784 & .005 \\
\hline & Within Groups & 201.735 & 195 & 1.035 & & \\
\hline & Total & 217.395 & 199 & & & \\
\hline \multirow[t]{3}{*}{$\mathrm{q} 20$} & Between Groups & 34.077 & 4 & 8.519 & 4.660 & .001 \\
\hline & Within Groups & 356.518 & 195 & 1.828 & & \\
\hline & Total & 390.595 & 199 & & & \\
\hline
\end{tabular}

\subsection{Hypotheses Results}

The research found that the students feel that the most important impact of competitive advantage on marketing of Jordanian universities is the university reputation between Arabs which is better than the true reality.

Female students feel more than the male students that the most important impact of competitive advantage on marketing of Jordanian universities is preferring the university, regardless of Arab and international recognitions and the quality and effectiveness of priority educational services priority for them when they chose the university. When they chose the university they did not care about fees price which increases comparison with other universities and ready to pay a higher price for better services for the university transportation. The quality of educational services is more important to them than the price they pay. Increasing the efficiency of human resources at the university found that the first year students feel more than the second year students that the biggest impact of competitive advantage on marketing of Jordanian universities is the university providing the highest quality of educational services which are compatible with the requirements of the current stage. Increasing the positive word of mouth about the university, locally, regionally and internationally. The Forth year students feel more than the second year students that the biggest impact of competitive advantage on marketing of Jordanian universities they are ready to pay a higher price for better services for the university transportation. And the price you pay to the university is equivalent to the benefit that they get.

The fifth year students feel more than the second year students that there is an increase the efficiency of human resources at the university.

The humanities students feel more than the science students that they are ready to pay a higher price versus better educational services for the university's physical environment.

The science students feel more than the humanities students that the university provided educational services are better than student's expectations.

Students in other specialties feel more than the humanities students that the biggest impact of competitive advantage on marketing Jordanian universities is the annual increase in the number of students at the university.

The students with scholarships feel more than the student with relatives support that the most impact of competitive advantage on marketing Jordanian universities is the choice of the university based on using varying educational tools.

The students with scholarship feel more than the students with family support that the most impact of competitive advantage on marketing Jordanian universities is the choice for the university based on using varying educational tools and when they choose the university they do not care about fees price increases comparison with other universities.

The non-Jordanian students feel more than the Jordanian students that the biggest impact of competitive advantage on marketing Jordanian universities is the choice of the university based on using vary educational tools and the quality and effectiveness of priority educational services priority for me during choosing the university. 
Table 5. ANOVA for the specialization variable

\begin{tabular}{lllllll}
\hline & & Sum of Squares & df & Mean Square & F & Sig. \\
\hline q1 & Between Groups & 12.221 & 2 & 6.110 & 3.142 & .045 \\
& Within Groups & 383.059 & 197 & 1.944 & & \\
& Total & 395.280 & 199 & & & \\
q7 & Between Groups & 37.903 & 2 & 18.952 & 8.986 & .000 \\
& Within Groups & 415.492 & 197 & 2.109 & & \\
& Total & 453.395 & 199 & & & .001 \\
q14 & Between Groups & 9.829 & 2 & 4.915 & 6.727 & \\
& Within Groups & 143.926 & 197 & .731 & & \\
& Total & 153.755 & 199 & & & .005 \\
q16 & Between Groups & 13.320 & 2 & 6.660 & 5.463 & \\
& Within Groups & 240.180 & 197 & 1.219 & & \\
& Total & 253.500 & 199 & & & \\
\hline
\end{tabular}

Table 6. ANOVA for the methods of payment variable

\begin{tabular}{lllllll}
\hline & & Sum of Squares & df & Mean Square & F & Sig. \\
\hline & Within Groups & 373.208 & 196 & 1.904 & & \\
q2 & Total & 395.280 & 199 & & & \\
& Between Groups & 21.444 & 3 & 7.148 & 4.874 & .003 \\
& Within Groups & 287.436 & 196 & 1.467 & & \\
& Total & 308.880 & 199 & & & \\
q3 & Between Groups & 35.761 & 3 & 11.920 & 7.639 & .000 \\
& Within Groups & 305.834 & 196 & 1.560 & & \\
& Total & 341.595 & 199 & & & \\
& Between Groups & 32.363 & 3 & 10.788 & 5.887 & .001 \\
& Within Groups & 359.157 & 196 & 1.832 & & \\
\hline
\end{tabular}

Table 7. T-test for the nationality variable

\begin{tabular}{lllll}
\hline nationality & & $\mathrm{q} 3$ & $\mathrm{q} 4$ & $\mathrm{q} 6$ \\
\hline 1.00 & Mean & 4.1942 & 4.2878 & 4.0935 \\
& $\mathrm{~N}$ & 139 & 139 & 139 \\
& Std. Deviation & 1.41359 & 1.32558 & 1.48369 \\
2.00 & Mean & 4.5246 & 4.4918 & 4.3770 \\
& $\mathrm{~N}$ & 61 & 61 & 61 \\
\multirow{2}{*}{ Total } & Std. Deviation & 1.01006 & .94204 & 1.18552 \\
& Mean & 4.2950 & 4.3500 & 4.1800 \\
& N & 200 & 200 & 200 \\
& Std. Deviation & 1.31017 & 1.22269 & 1.40265 \\
\hline
\end{tabular}

\section{Conclusions}

Based on the above results, the research concludes there are significant statistical evidences that influence the difference between the impacts of competitive advantage on marketing of Jordanian universities. These differences are due to the following factors:
a. Gender of the student.
b. Study level of the student
c. Specialty of the student
d. Nationality of the student
e. Ways of payment

\section{Recommendations}

Based on the above conclusion and in order to lighten the impact of competitive advantage on marketing of Jordanian universities, the study recommends the following:

1) Jordanian universities should develop recruitment and employment to increase the efficiency and the 
effectiveness.

2) The universities in Jordan must conduct training courses.

3) Providing employees with the required information, and develop their abilities, skills, and attitudes.

4) It is necessary for universities to develop a job description system.

\section{Future Studies}

Conclusions of the previous studies, as well as the conclusions of this study, are worth investigation and revision by researchers; hence the researcher recommends conducting the following studies:

1) Effects of competitive advantages on marketing Jordanian universities.

2) Relationships between students' needs and the impact of competitive advantages on marketing Jordanian universities.

3) Effects of leadership style.

\section{References}

Akonkwa, D. (2009). Is market orientation a relevant strategy for higher education institutions?: Context analysis and research agenda. International Journal of Quality and Service Sciences, 1(3).

Aydin, O. T. (2013). Location as a Competitive Advantage to Attract Students: An Empirical Study from a Turkish Foundation University. International Review of Management and Marketing, 3(4), 204-211.

Barney, J. (1991). Firm Resources and Sustained Competitive Advantage. Journal of Management, 17(1), 99-120. http://dx.doi.org/10.1177/014920639101700108

Barney, J. B., \& Arikan, A. M. (2001). The Resource-Based View: Origins and Implications. The Blackwell Handbook of Strategic Management, 124-188.

Buhalis, D. (2008). Marketing the competitive destination of the future university of Westminster. Retrieved from http://epubs.surrey.ac.uk./1087/1/fulltext.pdf

Burdett, J., \& Crossman, J. (2010). Checking the pulse: The international student experience and social engagement across Australian universities: reflecting on AUQA feedback to Cycle 2 reports. Journal of International Education in Business, 3(1/2). http://dx.doi.org/10.1108/18363261011106885

Duncan, J., Gintei, P. M., \& Swayne, L. E. (1998). Competitive advantage\& internal organizational assessment. Academy of ManagementExecutive, 12(3). http://dx.doi.org/10.5465/ame.1998.1109046

Fernandes, C., Ross, K., \& Meraj, M. (2013). Understanding Student Satisfaction and Loyalty in the UAE HE Sector. International Journal of Educational Management, 27(6). http://dx.doi.org/10.1108/ijem-07-2012-0082

Gallego-Álvarez, I., Rodríguez-Domínguez, L., \& García-Sánchez, I. M. (2011). Information disclosed online by Spanish universities: content and explanatory factors. Online Information Review, 35(3). http://dx.doi.org/10.1108/14684521111151423

Haan, H. H. D. (1987). Competiitve Advantage, What Does it Really Mean in the Context of Public Higher Education Institutions? International Journal of Educational Management, 29(1), 44-61. http://dx.doi.org/10.1108/IJEM-07-2013-0115

Hamel, G., \& Prahalad, C. K. (1994). Competing for the Future. MA: Boston Harvard Business School Press.

Lim, M., \& Svensson, P. (2013). Embedding critique in the university: a new role for critical marketing education? Journal of Applied Research in Higher Education, 5(1). http://dx.doi.org/10.1108/17581181311310252

Lombardo, J. (2015). Types of Competitive Advantage Cost Product Niche Sustainable Advantages. http://study.com/academy/lesson/.html

Mazzarol, T., \& Soutar, G. N. (2012). Revisiting the global market for higher education. Asia Pacific Journal of Marketing and Logistics, 24(5).

McManus, T. E. (2014). Dreams, visions, and values in fundamental Business Education. Journal of Management Development, 33(1), 32-47. http://dx.doi.org/10.1108/JMD-11-2013-0134

Mourad, M. (2010). Students' adoption of an open access online education service: An exploratory study in an 
emerging higher education (HE) market. Online Information Review, 34(4).

Petruzzellis, L., \& Romanazzi, S. (2010). Educational value: how students choose university: Evidence from an Italian university. International Journal of Educational Management, 24(2). http://dx.doi.org/10.1108/09513541011020954

Porter, M. (1985). Competitive Strategy, Techniques for analyzing Industries and Competitors. Strategic Management Journal, 12, 95-117. http://dx.doi.org/10.1002/smj.4250121008

Prahalad, C. K., \& Hamel, G. (1990). The Core Competency of the Corporation. Harvard Business Review, $68(3), 82$.

Ramachandran, N. T. (2010). Marketing framework in higher education: Addressing aspirations of students beyond conventional tenets of selling products. International Journal of Educational Management, 24(6). http://dx.doi.org/10.1108/09513541011067700

Stalk, G., Evans, P., \& Shulman, L. (1992). Competing on capabilities: The new rules of corporate strategy. Haivaid Business Review, 70(2).

Stanton, A. D. (2006). Bridging the academic/practitioner divide in marketing: An undergraduate course in data mining. Marketing Intelligence \& Planning, 24(3), 233-244. http://dx.doi.org/10.1108/02634500610665709

Wernerfelt, B. (1984). A resource Based View of the Firm. Strategic Management Journal, 5(2), 171-180. http://dx.doi.org/10.1002/smj.4250050207

Yeo, R. K. (2008). Servicing Service Quality in Higher Education: Quest for Excellence. On the Horizon, 16(3), 152-161. http://dx.doi.org/10.1108/10748120810901459

Yeo, R. K., \& Li, J. (2014). Beyond SERVQUAL: The competitive forces of higher education in Singapore. Total Quality Management and Business Excellence, 25(1-2). http://dx.doi.org/10.1080/14783363.2011.637802

Zebal, M. A., \& Goodwin, D. R. (2012). Market orientation and performance in private universities. Marketing Intelligence \& Planning, 30(3).

\section{Copyrights}

Copyright for this article is retained by the author(s), with first publication rights granted to the journal.

This is an open-access article distributed under the terms and conditions of the Creative Commons Attribution license (http://creativecommons.org/licenses/by/3.0/). 